\title{
PRODUCTIVITY ANALYSIS OF ERGONOMIC CHAIR FOR OPERATOR POND MACHINE
}

\author{
M. Nushron Ali Mukhtar ${ }^{1}$, Am. Mufarich ${ }^{2}$ \\ ${ }^{1}$ Department of Industrial Engineering Faculty of Industrial Technology \\ University of PGRI Adi Buana Surabaya \\ ${ }^{2}$ Department of Mechanical Engineering, Politeknik Negri Malang
}

\begin{abstract}
There is a previous study analyzing the design of ergonomic chairs for pond machine operators, where the analysis uses the RULA method manually, Based on the results of data processing with the RULA method, it can be concluded that the posture of the ring making operator (washer) operator with a slightly bent body position has a score value 5, and the chair design based on the redesign of the pond engine operator chair shows that the final result is 3. (Mukhtar, 2018) In this study, a productivity analysis is carried out to measure the level of chair productivity by considering several aspects of work activities, The method used is the Objective Matrix (OMAX) and the determination of the score from the performance appraisal using the Analytical Hierarchy Process (AHP) method. The results obtained are Productivity increased from before, because it is still in the range of 3-10 (based on the matrix table the score 3-5 is good enough, 6-8 good and 9-10 very good) and the lowest values shown in this table are 3 and 4 Based on the scores, the scores are still quite good. But there still must be improvement. Overall the level of productivity has increased compared to before. But there are still fluctuating data. This is due to the lack of uniformity in the ability of the opeator to run the pond engine in washer production.
\end{abstract}

Keyword :Productivity, Ergonomics Chair, Pond Machine

\section{INTRODUCTION}

Every industry, both large and small, wants to maintain its business to survive in the face of competitive competition, companies must improve internally, one of them is by increasing productivity. Because this will make the company grow. Productivity is a picture of the company's achievements (Agustin \& Riana, 2011) which is able to provide an overview of the relationship of output and input used to produce output (Zanuar, 2014).

The obstacle of the company in increasing productivity on the production floor is generally influenced by the inappropriate use of resources during production activities. For this reason, productivity measurements are needed on the production floor (Avianda et al., 2014). By measuring this productivity the company is able to find out the level of productivity that has been achieved and can be used as a foundation for the company's future planning (Zanuar, 2014). So, companies can evaluate the factors that affect changes in productivity of the company (Pangaula et al., 2015)

This increase in productivity is closely related to efforts to improve the level of a country's economy and to strengthen Indonesia's position in increasingly fierce world trade competition. On a company scale, it is hoped that there will be efforts to increase productivity, which in turn can support national productivity

Productivity measurement is done by taking into account the condition of the company, so that the size obtained is able to provide a clear picture of the level of productivity of the company (Zanuar, 2014). The inefficient and effective use of raw material, labor, energy, and machine resources during production activities encourages companies to increase productivity. Therefore companies need to take productivity measurements to find out the dominant factors that influence productivity.

In previous studies analyzing the design of ergonomic chairs for pond machine operators, where the analysis using the RULA method manually, Based on the results of data processing with the RULA method, it can be concluded that the posture of the ring making operator (washer) operator with a slightly bent body position has a score value 5 , and the 
chair design based on the redesign of the pond engine operator chair shows that the final result is 3. (Mukhtar, 2018)

The purpose of this research is to measure the level of productivity of the design of ergonomic chair designs used by pond machine operators. Considering the important role of the production process activities carried out by pond machine workers in the metal industry, where labor plays a dominant role, it should be done study to analyze and evaluate work postures.

In this research, productivity analysis was carried out to measure the level of chair productivity by considering several aspects of work activities, the method used was Objective Matrix (OMAX). The productivity measurement method used is the Objective Matrix (OMAX) method and for determining the score of the performance appraisal using the Analytical Hierarchy Process (AHP) method. In this method provides an overview of the state of company productivity. Raw material is one of the important components of input which acts as a basic material in washer production. And also labor is one of the input components that acts as the manager of the management system and with the machine runs the production process.

Based on these problems, it is necessary to measure how effective and efficient the washer component production process uses an ergonomic chair for the pond machine operator.

\section{METOD}

Data processing using the method developed by James L. Riggs has the following stages (Riggs, 1986 referred to in the Balkans, 2010):

a. Determine measurement objectives

b. Determine measurement criteria

c. Determine the performance ratio

Performance is the level of productivity which is the ratio of each measurement criterion. Performance value is obtained by dividing the ratio of inputs with outputs on each criterion.

d. Determine the target (Faridz et al., 2010).

Determine the Final Target Target (Score 10) The value of the score of 10 is obtained from the BKA (Upper Control Limit) which is the maximum productivity limit that the company might achieve from each productivity criterion. The BKA, DA (Degree of Accuracy), and CL (Confident Level) formulas are:

$\mathrm{B} K \mathrm{~A}=\mu+\mathrm{k} . \sigma \ldots \ldots \ldots \ldots(1)$
$\mathrm{DA}=\mathrm{DA}=/ \sigma \times 100 \ldots \ldots \ldots \ldots$
$\mathrm{CL}=100 \%$ - $\mathrm{DA} . \ldots \ldots \ldots \ldots \ldots(3)$
Information:

BKA: Upper Control Limit.

: The average of each criterion measured.

$\sigma:$ Standard Deviation.

$\mathrm{k}$ : Constants.

$\mathrm{k}: 1$, if the confidence level (CL) lies at $0 \% \leq$ $\mathrm{CL} \leq 68 \%$.

$\mathrm{k}: 2$, if the confidence level (CL) lies at $68 \%$ $<\mathrm{CL} \leq 95 \%$.

$\mathrm{k}: 3$, if the confidence level (CL) lies at $95 \%$ $<\mathrm{CL} \leq 99.7 \%$.

Determining Short-Term Goals (Score 3 ) The value on the score 3 is the value of productivity that has been achieved so far. The score on score 3 is obtained by averaging the radio values for each criterion. The formula to calculate the average is:

$$
=1 /\left(n \sum(i=1)^{\wedge} n \nLeftarrow \mathbf{X} i\right)
$$

Information :

$\mu$ : The average of each criterion measured for 3 months

$\mathrm{n}$ : amount of data

$\mathrm{Xi}$ : The ratio of each criterion

Determine the Lowest Productivity Value (Score 0) The value on the score 0 is obtained from the BKB (Lower Control Limit) which is the minimum productivity limit that may be achieved by the company. The BKB formula is:

$\mathrm{B} K \mathrm{~A}=\mu-\mathrm{k} . \sigma \ldots \ldots \ldots . .(5)$

Determine realistic productivity values (Score 1-2 and Score 4-9) Realistic productivity values are values that might be achieved before the final goal. Scores 1-2 and scores 4-9 are obtained from interpolation. The interpolation formula used is (Balkan, 2010):

$$
\begin{array}{ll}
h & \square-s=\frac{s}{s-s} \mathrm{u} \\
h & s-1 . .(6)
\end{array}
$$

Determining the value of criteria weights Determining the weight of each criterion is emphasized in determining the priority value of criteria by comparing which is more important between criteria. To make it 


\section{Tibuana}

Journal of applied Industrial Engineering-University of PGRI Adi Buana

p-ISSN 2622-2027

$e$-ISSN 2622-2035

easier to determine priorities, it is necessary to make a conversion table of priority statements

into numbers. Following is a table of priority criteria used (Agustina \& Riana, 2011).

Table 1. Priority Scale Criteria

\begin{tabular}{ll}
\hline Value & \multicolumn{1}{c}{ Value Priority Level } \\
\hline 1 & CRITERIA 1 is as important as CRITERIA 2 \\
2 & CRITERIA 1 is slightly more important than CRITERIA 2 \\
7 & CRITERIA 1 is more important than CRITERIA 2 \\
9 & CRITERIA 1 is very important compared to CRITERIA 2 \\
$3,4,6,8$ & CRITERIA $1 *$ ) middle value
\end{tabular}

3. RESULT

a. Determine research objectives

The purpose of this study was

to determine the level of productivity

of workers / operators of pond

machines before and after using

ergonomic chairs using the OMAX

method.

\section{b. Establish Criteria}

The criteria to be measured are 4 criteria:

1) Criteria 1 is the amount of material used per hour.
2) Criteria 2 is the number of defective rings

3) Criteria 3 is the amount of operator productive time

These three criteria are the input in this study and the output is the amount of ring / washer production without defects. The data is obtained from historical data of the engine operator when using ergonomic chairs in July 2019 - September 2019. Input and output data can be seen in Table 2 .

Table 2 Input and output data

\begin{tabular}{|c|c|c|c|c|}
\hline \multirow[b]{2}{*}{ Operator } & \multicolumn{3}{|c|}{ Input } & \multirow{2}{*}{$\begin{array}{c}\text { Output } \\
\text { washer } \\
\text { without } \\
\text { defect }(\mathrm{Kg})\end{array}$} \\
\hline & $\begin{array}{l}\text { Material } \\
\text { used (Kg) }\end{array}$ & $\begin{array}{l}\text { washer defect } \\
\text { (Pcs) }\end{array}$ & $\begin{array}{l}\text { Productive time } \\
\text { (Jam) }\end{array}$ & \\
\hline A & 87.32 & 183.21 & 4.55 & 35.51 \\
\hline B & 85.43 & 207.98 & 3.42 & 38.42 \\
\hline c & 75.78 & 140.12 & 5.12 & 28.89 \\
\hline D & 86.19 & 190.38 & 4.23 & 39.54 \\
\hline E & 82.45 & 126.93 & 3.57 & 34.33 \\
\hline $\mathrm{F}$ & 78.65 & 118.22 & 5.3 & 29.24 \\
\hline G & 82.67 & 201.83 & 4.32 & 35.43 \\
\hline $\mathrm{H}$ & 90.31 & 198.94 & 5.43 & 42.11 \\
\hline
\end{tabular}

\section{c. Performance ratio}

Performance values indicate

each unit of resource used. Values are calculated by output / input. the number of products produced from 


\section{Tibuana}

Journal of applied Industrial Engineering-University of PGRI Adi Buana

Performance values can be seen in the

following.

Table 4.

Table 3 Value of Performance Ratio

\begin{tabular}{cccc}
\hline Operator & $\begin{array}{c}\text { Material } \\
\text { used } \\
\text { (Kg) }\end{array}$ & $\begin{array}{c}\text { Input } \\
\text { washer } \\
\text { defect (Pcs) }\end{array}$ & $\begin{array}{c}\text { Productive } \\
\text { time } \\
\text { (Jam) }\end{array}$ \\
\hline A & 28.093 & 13.390 & 539.147 \\
B & 33.248 & 13.657 & 662.093 \\
C & 22.723 & 12.289 & 336.324 \\
D & 36.229 & 16.402 & 738.189 \\
E & 31.926 & 20.738 & 563.668 \\
F & 26.983 & 17.952 & 423.601 \\
G & 33.343 & 13.657 & 638.063 \\
H & 38.070 & 17.282 & 633.169 \\
Rata- rata & 31.33 & 15.67 & 566.78 \\
StandarDeviasi & 5.08 & 2.90 & 132.20 \\
\hline
\end{tabular}

d. Target

1) Final Target Target (Score 10)

Criteria for Material Use

$\sigma=5.08 ; \quad=31.33$

Accuracy Level DA $=\sigma / \times 100 \%$

$\mathrm{DA}=5.08 / 31.33 \times 100 \%=0.163$

Confidence level $\mathrm{CL}=100 \%-\mathrm{DA}=$ 0.837
$\mathrm{UCL}=+\mathrm{k} \cdot \sigma(\mathrm{k}=2$. Because CL lies at $68 \%<\mathrm{CL} \leq 95 \%$.)

$\mathrm{UCL}=31.33+2 \times 5.33=41.49$

Score 10 is the productivity value expected by the company in this case UKM. So to find out all the final targets on each input criteria used, it can be seen in the following table 4 .

Table 4 final targets for each input criterion

\begin{tabular}{cccc}
\hline Operator & $\begin{array}{c}\text { Material } \\
\text { used (Kg) }\end{array}$ & $\begin{array}{c}\text { Input } \\
\text { washer } \\
\text { defect (Pcs) }\end{array}$ & $\begin{array}{c}\text { Productive } \\
\text { time } \\
(\mathbf{J a m})\end{array}$ \\
\hline DA & 0.162 & 0.184 & 0.233 \\
CL & 0.837 & 0.815 & 0.766 \\
UCL & 41.49 & 21.46 & 831.18 \\
\hline
\end{tabular}

2) Short-term target (Score 3)

Criteria of material used

$\mu=\frac{1}{y} \sum_{[=1}^{\forall} 87.32+\cdots \cdots+90.31=$

31.33

Criteria of washer defect $\mu=\frac{1}{y} \sum_{[=1}^{b} 183.21+\cdots \cdots+198.94=$ 15.67

Criteria of productive time

$\mu=\frac{1}{y} \sum_{[=1}^{\forall} 4.55+\cdots \cdots+5.43=$ 566.78 
3) Target sasaranTerburuk (Skor 0)

Criteria of material used

$\sigma=5.08 ; \quad=31.33$

$\mathrm{LCL}=\mathrm{UCL}=-\mathrm{k} \cdot \sigma(\mathrm{k}=2$. Beacause

CL lies on $68 \%<\mathrm{CL} \leq 95 \%$.)

Table 5 Worst Target

\begin{tabular}{cccc}
\hline Operator & $\begin{array}{c}\text { Material } \\
\text { used } \\
(\mathbf{K g})\end{array}$ & $\begin{array}{c}\text { Input } \\
\text { wefect }(\mathbf{P c s})\end{array}$ & $\begin{array}{c}\text { Productive } \\
\text { time } \\
\text { (Jam) }\end{array}$ \\
\hline DA & 0.162298 & 0.184886359 & 0.233247 \\
CL & 0.837702 & 0.815113641 & 0.766753 \\
LCL & 21.15835 & 9.876211073 & 302.3819 \\
\hline
\end{tabular}

e. Realistic Productivity Rating (Score 1-2 and Score 4-9)

Criteria for material use

The interval between the score is 0 to 3
Interval0-3 $=(\mathrm{UCL}-\mathrm{LCL}) / 3=(41.49$ -

21.158) $/ 3=6.78$

Intervalbetween thescore3 to 10

Interval3-10 $=($ UCL-LCL $) / 7=(41.49-$

$21.158) / 7=4.96$

Table 6 Recap of realistic productivity values for all criteria

\begin{tabular}{cccc}
\hline & \multicolumn{3}{c}{ Input } \\
\cline { 2 - 4 } Operator & $\begin{array}{c}\text { Material } \\
\text { used } \\
(\mathbf{K g})\end{array}$ & $\begin{array}{c}\text { washer } \\
\text { defect (Pcs) }\end{array}$ & $\begin{array}{c}\text { Productive } \\
\text { time } \\
\text { (Jam) }\end{array}$ \\
\hline DA & 0.16 & 0.18 & 0.23 \\
CL & 0.84 & 0.82 & 0.77 \\
UCL & 41.50 & 21.47 & 831.18 \\
LCL & 21.16 & 9.88 & 302.38 \\
skor 0-3 & 6.78 & 3.86 & 176.27 \\
skor 3-10 & 4.96 & 2.51 & 93.56 \\
\hline
\end{tabular}

f. Criteria Weight Value

Determination of criteria weights by comparing each criterion is shown in table 7 below.

Table 7. Comparison of priorities for each criterion

\begin{tabular}{lccc}
\hline & $\begin{array}{c}\text { Material } \\
\text { used (Kg) }\end{array}$ & $\begin{array}{c}\text { washer } \\
\text { defect (Pcs) }\end{array}$ & $\begin{array}{c}\text { washer } \\
\text { defect } \\
\text { (Pcs) }\end{array}$ \\
\hline $\begin{array}{l}\text { Material } \\
\text { used (Kg) }\end{array}$ & 1 & 2 & 3 \\
\hline $\begin{array}{l}\text { washer } \\
\text { defect (Pcs) }\end{array}$ & $1 / 2$ & 1 & $1 / 5$ \\
\hline $\begin{array}{l}\text { washer } \\
\text { defect (Pcs) }\end{array}$ & $1 / 3$ & 5 & 1 \\
\hline
\end{tabular}


Based on the results of weighting in table 4.6 the next step is to determine the weighting that ranges from $0-1$ and the total weight of each column is 1 . The weight calculation is

Table 8. Value comparison of priority of each criterion

\begin{tabular}{cccc}
\hline & $\begin{array}{r}\text { Material } \\
\text { used (Kg) }\end{array}$ & $\begin{array}{c}\text { washer } \\
\text { defect } \\
\text { (Pcs) }\end{array}$ & $\begin{array}{c}\text { washer } \\
\text { defect } \\
\text { (Pcs) }\end{array}$ \\
\hline Material used (Kg) & 0.545 & 0.250 & 0.714 \\
washer defect (Pcs) & 0.273 & 0.125 & 0.048 \\
washer defect (Pcs) & 0.182 & 0.625 & 0.238 \\
\hline
\end{tabular}

Then look for the weights of each criterion by adding up the weights in one row in table 9 with the number of columns. So each criterion is:

Criteria for material use $=(0.545+$ $0.250+0.714) / 3=0.504$

Criteria for ring / washer defect $=$ $(0.273+0.125+0.048) / 3=0.148$
Criteria for productive time $=(0.182+$ $0.625+0.238) / 3=0.348$

The result of all weighting is $1(100 \%)$ After doing the steps for making the initial matrix. Next is to do the weighting of the four criteria that are grouped on each individual / worker, and the results of the weighting can be seen in the following table 4.8 .

Table 9 results of weighting of workers A

\begin{tabular}{cccc}
\hline & $\begin{array}{c}\text { Material } \\
\text { used } \\
(\text { Kg) }\end{array}$ & $\begin{array}{c}\text { washer } \\
\text { defect (Pcs) }\end{array}$ & $\begin{array}{c}\text { washer defect } \\
\text { (Pcs) }\end{array}$ \\
\hline Performance & 28.09 & 13.39 & 539.147 \\
10 & 41.49 & 21.47 & 831.18 \\
9 & 36.53 & 18.96 & 737.62 \\
8 & 31.57 & 16.45 & 644.06 \\
7 & 26.61 & 13.94 & 550.50 \\
6 & 21.65 & 11.43 & 456.94 \\
5 & 16.69 & 8.92 & 363.38 \\
4 & 11.73 & 6.41 & 269.82 \\
3 & 31.33 & 15.67 & 566.78 \\
2 & 24.55 & 11.81 & 363.78 \\
1 & 17.77 & 7.95 & 187.51 \\
0 & 21.16 & 9.88 & 302.38 \\
Score & 7 & 2 & 6 \\
Weigth & 0.504 & 0.148 & 0.348 \\
Value & 3.528 & 0.296 & 2.088 \\
Total & & 5.912 & \\
\hline
\end{tabular}




\section{Tibuana}

Journal of applied Industrial Engineering-University of PGRI Adi Buana

Table 10 Work achievements of each operator

\begin{tabular}{cc}
\hline Operator & $\begin{array}{c}\text { Work } \\
\text { achievement }\end{array}$ \\
\hline A & 3.592 \\
B & 9.208 \\
C & 4.132 \\
D & 9.2 \\
E & 7.06 \\
F & 4.932 \\
G & 8.356 \\
H & 9.156 \\
\hline
\end{tabular}

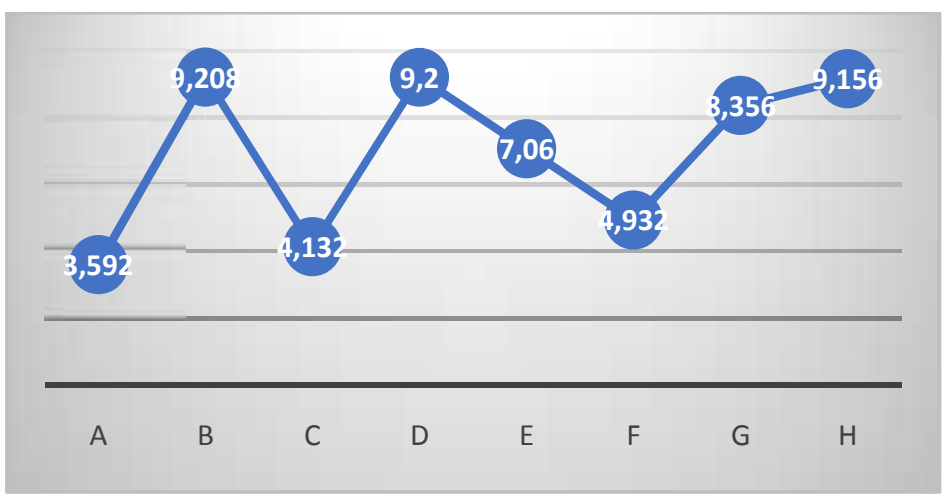

Figure 1 Graphic productivity before using tools

Then after doing the calculations for all weights to the achievement of performance for each operator. Then compared between before using the operator seat.

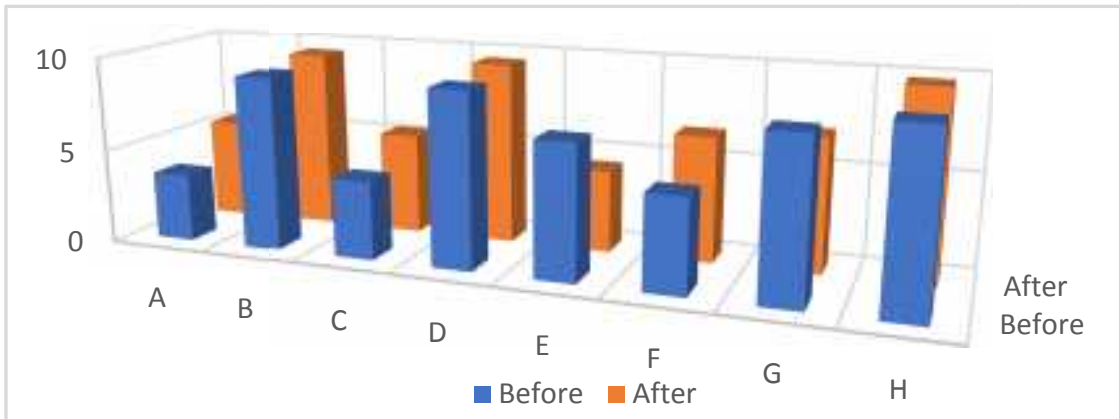

Figure 2 comparison of the productivity of the use of a chair

Based on the analysis of data retrieval that has been processed using the OMAX method, the following data are obtained for the productivity of the pond engine operator after using an ergonomic chair. 
Table 11 results of weighting productivity after using an ergonomic chair

\begin{tabular}{cccc}
\hline Operator & $\begin{array}{c}\text { Material } \\
\text { used (Kg) }\end{array}$ & $\begin{array}{c}\text { washer } \\
\text { defect (Pcs) }\end{array}$ & $\begin{array}{c}\text { washer } \\
\text { defect (Pcs) }\end{array}$ \\
\hline A & 7 & 10 & 6 \\
B & 9 & 4 & 3 \\
C & 8 & 6 & 8 \\
D & 10 & 8 & 9 \\
E & 4 & 9 & 10 \\
F & 6 & 7 & 6 \\
G & 7 & 3 & 8 \\
Total & 51 & 47 & 50 \\
\hline
\end{tabular}

Based on the above table, in general it can be concluded that productivity increased from before, because it is still in the range of 3-10 (based on the matrix table the score 3-5 is good enough, 6-8 good and 9-10 very good) and the lowest value is shown in these tables are 3 and 4 . Based on the scores the scores are still quite good. But there still must be improvement. A value of 3 is obtained for operator $\mathrm{G}$ for the defective ring / washer criterion and for operator $\mathrm{B}$ for the Earning Time criteria. A set of 4 scores was obtained from operator $\mathrm{E}$ on the material used criteria and on operator $\mathrm{B}$ on the defective ring / washer criterion.

\section{CONCLUSION}

Productivity increased from before, because it is still in the range of 3-10 (based on the matrix table the scores are quite good 35, 6-8 good and 9-10 very good) and the lowest values shown in this table are 3 and 4 . Based on the score scores it is still quite good. But there still must be improvement. A value of 3 is obtained for operator $G$ for the defective ring / washer criterion and for operator $\mathrm{B}$ for the Earning Time criteria. Whereas the score 4 is obtained from the $\mathrm{E}$ operator on the used material criteria and on the B operator on the defective ring / washer criteria. Overall the level of productivity has increased compared to before. But there are still fluctuating data. This is due to the lack of uniformity in the ability of the opeator to run the pond engine in washer production.

\section{REFERENCE}

1. Agustina, F.,Riana,N.A. (2011). Analisa Produktivitas dengan Metode Objective Matrix (OMAX) di PT.X.Universitas Trunojoyo, 6(2), 150-158.

2. Avianda, D., Yuniati,Y., Yuniar. (2014). Strategi Peningkatan Produktivitas di Lantai Produksi Menggunakan Metode Objective Matrix (OMAX).Jurnal Online Institut Teknologi Nasional, 01(04).

3. Balkan D.2010. Enterprise Productivity Measuremnetin Services by OMAX (Objective Matrix) Method and An Application with Turkish Emergency Services. Dilihat 18 Desember 2015.

4. Faridz, R., Burhan, Wijayantie, A.E. (2010). Pengukuran dan Analisis Produktivitas Produksi dengan Metode Objective Matrix (OMAX) di PG. Krebet Baru Malang. Universitas Trunojoyo,

5. M. N. A. Mukhtar and T. Koesdijati, "Analisis Postur Kerja Pada Operator Mesin Pond Dengan Menggunakan Metode Rula," p. 8, 2018.

6. Pangaula, S.F., Saroyo, P., Widodo, K.H.. (2015). Pengukuran Produktivitas di PT. Madusari Nusa perdana Boyolali. Universitas Gadjah Mada. Sumanth DJ. 2000. Productivity Engineering and Managemnet. NewYork: McGraw Hill Book Company.

7. Zanuar,R. A.,Suharno. (2014). Pengukuran Produktivitas pada Lini Produksi di PTPN IX (PERSERO) Kopi Banaran Menggunakan Metode Objective Matrix (OMAX). Universitas Gadjah Mada. 


\title{
PRODUCTIVITY ANALYSIS OF ERGONOMIC CHAIR FOR OPERATOR POND MACHINE
}

\author{
M. Nushron Ali Mukhtar ${ }^{1}$, Am. Mufarich ${ }^{2}$ \\ ${ }^{1}$ Department of Industrial Engineering Faculty of Industrial Technology \\ University of PGRI Adi Buana Surabaya \\ ${ }^{2}$ Department of Mechanical Engineering, Politeknik Negri Malang \\ E-mail : nushronali85@gmail.com
}

\begin{abstract}
There is a previous study analyzing the design of ergonomic chairs for pond machine operators, where the analysis uses the RULA method manually, Based on the results of data processing with the RULA method, it can be concluded that the posture of the ring making operator (washer) operator with a slightly bent body position has a score value 5, and the chair design based on the redesign of the pond engine operator chair shows that the final result is 3. (Mukhtar, 2018) In this study, a productivity analysis is carried out to measure the level of chair productivity by considering several aspects of work activities, The method used is the Objective Matrix (OMAX) and the determination of the score from the performance appraisal using the Analytical Hierarchy Process (AHP) method. The results obtained are Productivity increased from before, because it is still in the range of 3-10 (based on the matrix table the score 3-5 is good enough, 6-8 good and 9-10 very good) and the lowest values shown in this table are 3 and 4 Based on the scores, the scores are still quite good. But there still must be improvement. Overall the level of productivity has increased compared to before. But there are still fluctuating data. This is due to the lack of uniformity in the ability of the opeator to run the pond engine in washer production.
\end{abstract}

Keyword :Productivity, Ergonomics Chair, Pond Machine

\section{INTRODUCTION}

Every industry, both large and small, wants to maintain its business to survive in the face of competitive competition, companies must improve internally, one of them is by increasing productivity. Because this will make the company grow. Productivity is a picture of the company's achievements (Agustin \& Riana, 2011) which is able to provide an overview of the relationship of output and input used to produce output (Zanuar, 2014).

The obstacle of the company in increasing productivity on the production floor is generally influenced by the inappropriate use of resources during production activities. For this reason, productivity measurements are needed on the production floor (Avianda et al., 2014). By measuring this productivity the company is able to find out the level of productivity that has been achieved and can be used as a foundation for the company's future planning (Zanuar, 2014). So, companies can evaluate the factors that affect changes in productivity of the company (Pangaula et al., 2015)

This increase in productivity is closely related to efforts to improve the level of a country's economy and to strengthen Indonesia's position in increasingly fierce world trade competition. On a company scale, it is hoped that there will be efforts to increase productivity, which in turn can support national productivity

Productivity measurement is done by taking into account the condition of the company, so that the size obtained is able to provide a clear picture of the level of productivity of the company (Zanuar, 2014). The inefficient and effective use of raw material, labor, energy, and machine resources during production activities encourages companies to increase productivity. Therefore companies need to take productivity measurements to find out the dominant factors that influence productivity.

In previous studies analyzing the design of ergonomic chairs for pond machine operators, where the analysis using the RULA method manually, Based on the results of data processing with the RULA method, it can be concluded that the posture of the ring making operator (washer) operator with a slightly bent body position has a score value 5 , and the 
chair design based on the redesign of the pond engine operator chair shows that the final result is 3. (Mukhtar, 2018)

The purpose of this research is to measure the level of productivity of the design of ergonomic chair designs used by pond machine operators. Considering the important role of the production process activities carried out by pond machine workers in the metal industry, where labor plays a dominant role, it should be done study to analyze and evaluate work postures.

In this research, productivity analysis was carried out to measure the level of chair productivity by considering several aspects of work activities, the method used was Objective Matrix (OMAX). The productivity measurement method used is the Objective Matrix (OMAX) method and for determining the score of the performance appraisal using the Analytical Hierarchy Process (AHP) method. In this method provides an overview of the state of company productivity. Raw material is one of the important components of input which acts as a basic material in washer production. And also labor is one of the input components that acts as the manager of the management system and with the machine runs the production process.

Based on these problems, it is necessary to measure how effective and efficient the washer component production process uses an ergonomic chair for the pond machine operator.

\section{METOD}

Data processing using the method developed by James L. Riggs has the following stages (Riggs, 1986 referred to in the Balkans, 2010):

a. Determine measurement objectives

b. Determine measurement criteria

c. Determine the performance ratio

Performance is the level of productivity which is the ratio of each measurement criterion. Performance value is obtained by dividing the ratio of inputs with outputs on each criterion.

d. Determine the target (Faridz et al., 2010).

Determine the Final Target Target (Score 10) The value of the score of 10 is obtained from the BKA (Upper Control Limit) which is the maximum productivity limit that the company might achieve from each productivity criterion. The BKA, DA (Degree of Accuracy), and CL (Confident Level) formulas are:

$\mathrm{B} K \mathrm{~A}=\mu+\mathrm{k} . \sigma \ldots \ldots \ldots \ldots(1)$
$\mathrm{DA}=\mathrm{DA}=/ \sigma \times 100 \ldots \ldots \ldots \ldots$
$\mathrm{CL}=100 \%$ - $\mathrm{DA} . \ldots \ldots \ldots \ldots \ldots(3)$
Information:

BKA: Upper Control Limit.

: The average of each criterion measured.

$\sigma:$ Standard Deviation.

$\mathrm{k}$ : Constants.

$\mathrm{k}: 1$, if the confidence level (CL) lies at $0 \% \leq$ $\mathrm{CL} \leq 68 \%$.

$\mathrm{k}: 2$, if the confidence level (CL) lies at $68 \%$ $<\mathrm{CL} \leq 95 \%$.

$\mathrm{k}: 3$, if the confidence level (CL) lies at $95 \%$ $<\mathrm{CL} \leq 99.7 \%$.

Determining Short-Term Goals (Score 3 ) The value on the score 3 is the value of productivity that has been achieved so far. The score on score 3 is obtained by averaging the radio values for each criterion. The formula to calculate the average is:

$$
=1 /\left(\mathrm{n} \sum(\mathrm{i}=1)^{\wedge} \mathrm{n} \% \mathrm{Xi}\right)
$$

Information :

$\mu$ : The average of each criterion measured for 3 months

$\mathrm{n}$ : amount of data

$\mathrm{Xi}$ : The ratio of each criterion

Determine the Lowest Productivity Value (Score 0) The value on the score 0 is obtained from the BKB (Lower Control Limit) which is the minimum productivity limit that may be achieved by the company. The BKB formula is:

$\mathrm{B} K \mathrm{~A}=\mu-\mathrm{k} . \sigma \ldots \ldots \ldots . . .(5)$

Determine realistic productivity values (Score 1-2 and Score 4-9) Realistic productivity values are values that might be achieved before the final goal. Scores 1-2 and scores 4-9 are obtained from interpolation. The interpolation formula used is (Balkan, 2010):

$$
\begin{array}{ll}
h & \square-s=\frac{s}{s-s} \mathrm{u} \\
h & s-1 . .(6)
\end{array}
$$

Determining the value of criteria weights Determining the weight of each criterion is emphasized in determining the priority value of criteria by comparing which is more important between criteria. To make it 


\section{Tibuana}

Journal of applied Industrial Engineering-University of PGRI Adi Buana

p-ISSN 2622-2027

$e$-ISSN 2622-2035

easier to determine priorities, it is necessary to make a conversion table of priority statements

into numbers. Following is a table of priority criteria used (Agustina \& Riana, 2011).

Table 1. Priority Scale Criteria

\begin{tabular}{ll}
\hline Value & \multicolumn{1}{c}{ Value Priority Level } \\
\hline 1 & CRITERIA 1 is as important as CRITERIA 2 \\
5 & CRITERIA 1 is slightly more important than CRITERIA 2 \\
7 & CRITERIA 1 is more important than CRITERIA 2 \\
9 & CRITERIA 1 is very important compared to CRITERIA 2 \\
$3,4,6,8$ & CRITERIA $1 *$ ) middle value
\end{tabular}

3. RESULT

a. Determine research objectives

The purpose of this study was

to determine the level of productivity

of workers / operators of pond

machines before and after using

ergonomic chairs using the OMAX

method.

\section{b. Establish Criteria}

The criteria to be measured are 4 criteria:

1) Criteria 1 is the amount of material used per hour.

Table 2 Input and output data

\begin{tabular}{|c|c|c|c|c|}
\hline \multirow[b]{2}{*}{ Operator } & \multicolumn{3}{|c|}{ Input } & \multirow{2}{*}{$\begin{array}{c}\text { Output } \\
\text { washer } \\
\text { without } \\
\text { defect (Kg) }\end{array}$} \\
\hline & $\begin{array}{l}\text { Material } \\
\text { used }(\mathrm{Kg})\end{array}$ & $\begin{array}{l}\text { washer defect } \\
\text { (Pcs) }\end{array}$ & $\begin{array}{l}\text { Productive time } \\
\text { (Jam) }\end{array}$ & \\
\hline$A$ & 87.32 & 183.21 & 4.55 & 35.51 \\
\hline B & 85.43 & 207.98 & 3.42 & 38.42 \\
\hline$C$ & 75.78 & 140.12 & 5.12 & 28.89 \\
\hline$D$ & 86.19 & 190.38 & 4.23 & 39.54 \\
\hline$E$ & 82.45 & 126.93 & 3.57 & 34.33 \\
\hline $\mathrm{F}$ & 78.65 & 118.22 & 5.3 & 29.24 \\
\hline G & 82.67 & 201.83 & 4.32 & 35.43 \\
\hline $\mathrm{H}$ & 90.31 & 198.94 & 5.43 & 42.11 \\
\hline
\end{tabular}

\section{c. Performance ratio}

Performance values indicate the number of products produced from each unit of resource used. Values are
2) Criteria 2 is the number of defective rings

3) Criteria 3 is the amount of operator productive time

These three criteria are the input in this study and the output is the amount of ring / washer production without defects. The data is obtained from historical data of the engine operator when using ergonomic chairs in July 2019 - September 2019. Input and output data can be seen in Table 2 . 


\section{Tibuana}

Journal of applied Industrial Engineering-University of PGRI Adi Buana

p-ISSN 2622-2027

$e$-ISSN 2622-2035

Table 4.

Table 3 Value of Performance Ratio

\begin{tabular}{cccc}
\hline Operator & $\begin{array}{c}\text { Material } \\
\text { used } \\
\text { (Kg) }\end{array}$ & $\begin{array}{c}\text { Input } \\
\text { washer } \\
\text { defect (Pcs) }\end{array}$ & $\begin{array}{c}\text { Productive } \\
\text { time } \\
\text { (Jam) }\end{array}$ \\
\hline A & 28.093 & 13.390 & 539.147 \\
B & 33.248 & 13.657 & 662.093 \\
C & 22.723 & 12.289 & 336.324 \\
D & 36.229 & 16.402 & 738.189 \\
E & 31.926 & 20.738 & 563.668 \\
F & 26.983 & 17.952 & 423.601 \\
G & 33.343 & 13.657 & 638.063 \\
H & 38.070 & 17.282 & 633.169 \\
Rata- rata & 31.33 & 15.67 & 566.78 \\
StandarDeviasi & 5.08 & 2.90 & 132.20 \\
\hline
\end{tabular}

d. Target

1) Final Target Target (Score 10)

Criteria for Material Use

$\sigma=5.08 ; \quad=31.33$

Accuracy Level DA $=\sigma / \times 100 \%$

$\mathrm{DA}=5.08 / 31.33 \times 100 \%=0.163$

Confidence level $\mathrm{CL}=100 \%-\mathrm{DA}=$ 0.837
$\mathrm{UCL}=+\mathrm{k} \cdot \sigma(\mathrm{k}=2$. Because CL lies at $68 \%<\mathrm{CL} \leq 95 \%$.)

$\mathrm{UCL}=31.33+2 \times 5.33=41.49$

Score 10 is the productivity value expected by the company in this case UKM. So to find out all the final targets on each input criteria used, it can be seen in the following table 4 .

Table 4 final targets for each input criterion

\begin{tabular}{cccc}
\hline Operator & $\begin{array}{c}\text { Material } \\
\text { used (Kg) }\end{array}$ & $\begin{array}{c}\text { Input } \\
\text { washer } \\
\text { defect (Pcs) }\end{array}$ & $\begin{array}{c}\text { Productive } \\
\text { time } \\
(\mathbf{J a m})\end{array}$ \\
\hline DA & 0.162 & 0.184 & 0.233 \\
CL & 0.837 & 0.815 & 0.766 \\
UCL & 41.49 & 21.46 & 831.18 \\
\hline
\end{tabular}

2) Short-term target (Score 3)

Criteria of material used

$\mu=\frac{1}{y} \sum_{[=1}^{\forall} 87.32+\cdots \cdots+90.31=$

31.33

Criteria of washer defect $\mu=\frac{1}{y} \sum_{I=1}^{\forall} 183.21+\cdots \cdots+198.94=$ 15.67

Criteria of productive time

$\mu=\frac{1}{y} \sum_{[=1}^{\forall} 4.55+\cdots \cdots+5.43=$ 566.78 
3) Target sasaranTerburuk (Skor 0)

Criteria of material used

$\sigma=5.08 ; \quad=31.33$

$\mathrm{LCL}=\mathrm{UCL}=-\mathrm{k} \cdot \sigma(\mathrm{k}=2$. Beacause

CL lies on $68 \%<\mathrm{CL} \leq 95 \%$.)

Table 5 Worst Target

\begin{tabular}{cccc}
\hline Operator & $\begin{array}{c}\text { Material } \\
\text { used } \\
(\mathbf{K g})\end{array}$ & $\begin{array}{c}\text { Input } \\
\text { wefect }(\mathbf{P c s})\end{array}$ & $\begin{array}{c}\text { Productive } \\
\text { time } \\
\text { (Jam) }\end{array}$ \\
\hline DA & 0.162298 & 0.184886359 & 0.233247 \\
CL & 0.837702 & 0.815113641 & 0.766753 \\
LCL & 21.15835 & 9.876211073 & 302.3819 \\
\hline
\end{tabular}

e. Realistic Productivity Rating (Score 1-2 and Score 4-9)

Criteria for material use

The interval between the score is 0 to 3
Interval0-3 $=(\mathrm{UCL}-\mathrm{LCL}) / 3=(41.49$ -

21.158) $/ 3=6.78$

Intervalbetween thescore3 to 10

Interval3-10 $=($ UCL-LCL $) / 7=(41.49-$

$21.158) / 7=4.96$

Table 6 Recap of realistic productivity values for all criteria

\begin{tabular}{cccc}
\hline & \multicolumn{3}{c}{ Input } \\
\cline { 2 - 4 } Operator & $\begin{array}{c}\text { Material } \\
\text { used } \\
(\mathbf{K g})\end{array}$ & $\begin{array}{c}\text { washer } \\
\text { defect }(\mathbf{P c s})\end{array}$ & $\begin{array}{c}\text { Productive } \\
\text { time } \\
(\text { Jam) }\end{array}$ \\
\hline DA & 0.16 & 0.18 & 0.23 \\
CL & 0.84 & 0.82 & 0.77 \\
UCL & 41.50 & 21.47 & 831.18 \\
LCL & 21.16 & 9.88 & 302.38 \\
skor 0-3 & 6.78 & 3.86 & 176.27 \\
skor 3-10 & 4.96 & 2.51 & 93.56 \\
\hline
\end{tabular}

f. Criteria Weight Value

Determination of criteria weights by comparing each criterion is shown in table 7 below.

Table 7. Comparison of priorities for each criterion

\begin{tabular}{lccc}
\hline & $\begin{array}{c}\text { Material } \\
\text { used (Kg) }\end{array}$ & $\begin{array}{c}\text { washer } \\
\text { defect (Pcs) }\end{array}$ & $\begin{array}{c}\text { washer } \\
\text { defect } \\
\text { (Pcs) }\end{array}$ \\
\hline $\begin{array}{l}\text { Material } \\
\text { used (Kg) }\end{array}$ & 1 & 2 & 3 \\
\hline $\begin{array}{l}\text { washer } \\
\text { defect (Pcs) }\end{array}$ & $1 / 2$ & 1 & $1 / 5$ \\
\hline $\begin{array}{l}\text { washer } \\
\text { defect (Pcs) }\end{array}$ & $1 / 3$ & 5 & 1 \\
\hline
\end{tabular}


Based on the results of weighting in table 4.6 the next step is to determine the weighting that ranges from $0-1$ and the total weight of each column is 1 . The weight calculation is

Table 8. Value comparison of priority of each criterion

\begin{tabular}{cccc}
\hline & $\begin{array}{r}\text { Material } \\
\text { used (Kg) }\end{array}$ & $\begin{array}{c}\text { washer } \\
\text { defect } \\
\text { (Pcs) }\end{array}$ & $\begin{array}{c}\text { washer } \\
\text { defect } \\
\text { (Pcs) }\end{array}$ \\
\hline Material used (Kg) & 0.545 & 0.250 & 0.714 \\
washer defect (Pcs) & 0.273 & 0.125 & 0.048 \\
washer defect (Pcs) & 0.182 & 0.625 & 0.238 \\
\hline
\end{tabular}

Then look for the weights of each criterion by adding up the weights in one row in table 9 with the number of columns. So each criterion is:

Criteria for material use $=(0.545+$ $0.250+0.714) / 3=0.504$

Criteria for ring / washer defect $=$ $(0.273+0.125+0.048) / 3=0.148$
Criteria for productive time $=(0.182+$ $0.625+0.238) / 3=0.348$

The result of all weighting is $1(100 \%)$ After doing the steps for making the initial matrix. Next is to do the weighting of the four criteria that are grouped on each individual / worker, and the results of the weighting can be seen in the following table 4.8 .

Table 9 results of weighting of workers A

\begin{tabular}{cccc}
\hline & $\begin{array}{c}\text { Material } \\
\text { used } \\
(\mathbf{K g})\end{array}$ & $\begin{array}{c}\text { washer } \\
\text { defect (Pcs) }\end{array}$ & $\begin{array}{c}\text { washer defect } \\
\text { (Pcs) }\end{array}$ \\
\hline Performance & 28.09 & 13.39 & 539.147 \\
10 & 41.49 & 21.47 & 831.18 \\
9 & 36.53 & 18.96 & 737.62 \\
8 & 31.57 & 16.45 & 644.06 \\
7 & 26.61 & 13.94 & 550.50 \\
6 & 21.65 & 11.43 & 456.94 \\
5 & 16.69 & 8.92 & 363.38 \\
4 & 11.73 & 6.41 & 269.82 \\
3 & 31.33 & 15.67 & 566.78 \\
2 & 24.55 & 11.81 & 363.78 \\
1 & 17.77 & 7.95 & 187.51 \\
0 & 21.16 & 9.88 & 302.38 \\
Score & 7 & 2 & 6 \\
Weigth & 0.504 & 0.148 & 0.348 \\
Value & 3.528 & 0.296 & 2.088 \\
Total & & 5.912 & \\
\hline
\end{tabular}




\section{Tibuana}

Journal of applied Industrial Engineering-University of PGRI Adi Buana

Table 10 Work achievements of each operator

\begin{tabular}{cc}
\hline Operator & $\begin{array}{c}\text { Work } \\
\text { achievement }\end{array}$ \\
\hline A & 3.592 \\
B & 9.208 \\
C & 4.132 \\
D & 9.2 \\
E & 7.06 \\
F & 4.932 \\
G & 8.356 \\
H & 9.156 \\
\hline
\end{tabular}

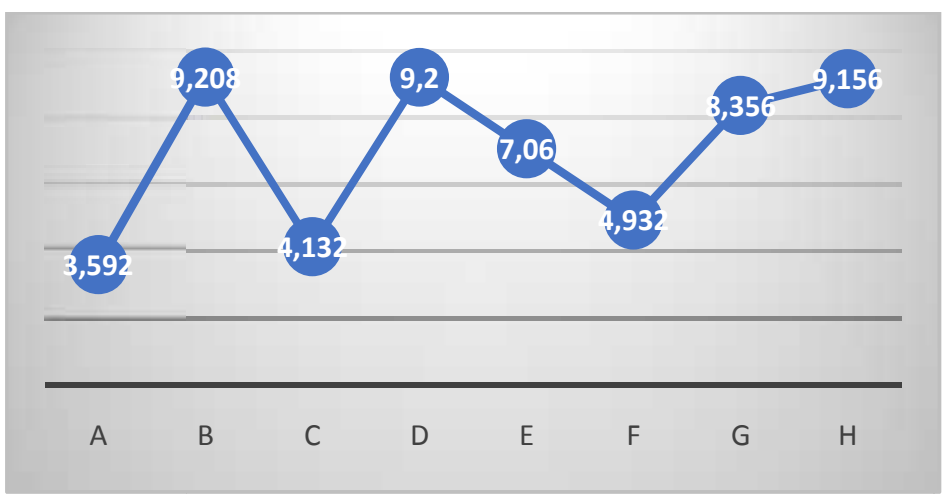

Figure 1 Graphic productivity before using tools

Then after doing the calculations for all weights to the achievement of performance for each operator. Then compared between before using the operator seat.

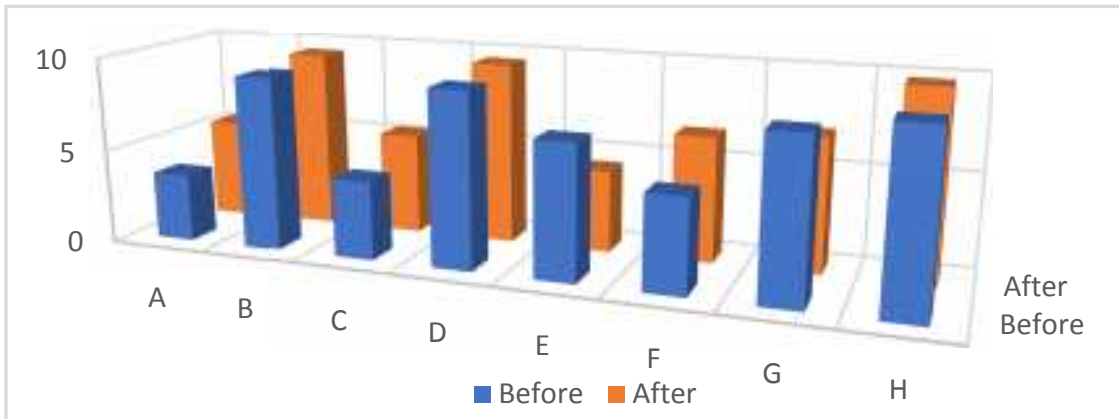

Figure 2 comparison of the productivity of the use of a chair

Based on the analysis of data retrieval that has been processed using the OMAX method, the following data are obtained for the productivity of the pond engine operator after using an ergonomic chair. 
Table 11 results of weighting productivity after using an ergonomic chair

\begin{tabular}{cccc}
\hline Operator & $\begin{array}{c}\text { Material } \\
\text { used (Kg) }\end{array}$ & $\begin{array}{c}\text { washer } \\
\text { defect (Pcs) }\end{array}$ & $\begin{array}{c}\text { washer } \\
\text { defect (Pcs) }\end{array}$ \\
\hline A & 7 & 10 & 6 \\
B & 9 & 4 & 3 \\
C & 8 & 6 & 8 \\
D & 10 & 8 & 9 \\
E & 4 & 9 & 10 \\
F & 6 & 7 & 6 \\
G & 7 & 3 & 8 \\
Total & 51 & 47 & 50 \\
\hline
\end{tabular}

Based on the above table, in general it can be concluded that productivity increased from before, because it is still in the range of 3-10 (based on the matrix table the score 3-5 is good enough, 6-8 good and 9-10 very good) and the lowest value is shown in these tables are 3 and 4 . Based on the scores the scores are still quite good. But there still must be improvement. A value of 3 is obtained for operator $\mathrm{G}$ for the defective ring / washer criterion and for operator $\mathrm{B}$ for the Earning Time criteria. A set of 4 scores was obtained from operator $\mathrm{E}$ on the material used criteria and on operator $\mathrm{B}$ on the defective ring / washer criterion.

\section{CONCLUSION}

Productivity increased from before, because it is still in the range of 3-10 (based on the matrix table the scores are quite good 35, 6-8 good and 9-10 very good) and the lowest values shown in this table are 3 and 4 . Based on the score scores it is still quite good. But there still must be improvement. A value of 3 is obtained for operator $G$ for the defective ring / washer criterion and for operator $\mathrm{B}$ for the Earning Time criteria. Whereas the score 4 is obtained from the $\mathrm{E}$ operator on the used material criteria and on the B operator on the defective ring / washer criteria. Overall the level of productivity has increased compared to before. But there are still fluctuating data. This is due to the lack of uniformity in the ability of the opeator to run the pond engine in washer production.

\section{REFERENCE}

1. Agustina, F.,Riana,N.A. (2011). Analisa Produktivitas dengan Metode Objective Matrix (OMAX) di PT.X.Universitas Trunojoyo, 6(2), 150-158.

2. Avianda, D., Yuniati,Y., Yuniar. (2014). Strategi Peningkatan Produktivitas di Lantai Produksi Menggunakan Metode Objective Matrix (OMAX).Jurnal Online Institut Teknologi Nasional, 01(04).

3. Balkan D.2010. Enterprise Productivity Measuremnetin Services by OMAX (Objective Matrix) Method and An Application with Turkish Emergency Services. Dilihat 18 Desember 2015.

4. Faridz, R., Burhan, Wijayantie, A.E. (2010). Pengukuran dan Analisis Produktivitas Produksi dengan Metode Objective Matrix (OMAX) di PG. Krebet Baru Malang. Universitas Trunojoyo,

5. M. N. A. Mukhtar and T. Koesdijati, "Analisis Postur Kerja Pada Operator Mesin Pond Dengan Menggunakan Metode Rula," p. 8, 2018.

6. Pangaula, S.F., Saroyo, P., Widodo, K.H.. (2015). Pengukuran Produktivitas di PT. Madusari Nusa perdana Boyolali. Universitas Gadjah Mada. Sumanth DJ. 2000. Productivity Engineering and Managemnet. NewYork: McGraw Hill Book Company.

7. Zanuar,R. A.,Suharno. (2014). Pengukuran Produktivitas pada Lini Produksi di PTPN IX (PERSERO) Kopi Banaran Menggunakan Metode Objective Matrix (OMAX). Universitas Gadjah Mada. 